\title{
Os museus de história natural como espaço de construção do saber
}

\author{
Natural history museums as a space for \\ constructing knowledge \\ Marcio Rangel \\ Pesquisador do Museu de Astronomia e Ciências Afins/ \\ Ministério da Ciência e Tecnologia. \\ Rua General Bruce, 586 \\ 20921-030 - Rio de Janeiro - RJ - Brasil \\ marciorangel@mast.br
}

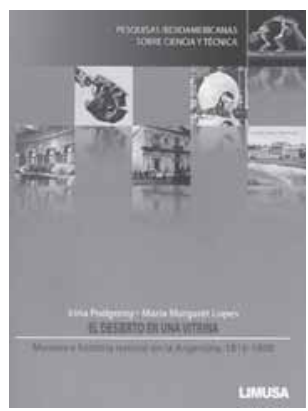

PODGORNY, Irina; LOPES, Maria Margaret. El desierto en una vitrina: museos e historia natural en la Argentina, 1810-1890. México: Limusa, 2008. 280p.
E sse livro, estruturado em nove capítulos, reúne uma série de ensaios sobre os museus de história natural da Argentina do século XIX: Museu Público de Buenos Aires, Museu Nacional do Paraná, Museu de Corrientes, Museus da Academia de Ciências de Córdoba, Museu Nacional deBuenosAires, Museu de La Plata, museus universitários e diversas outras instituições também assim denominadas, que surgem no seio das sociedades eruditas metropolitanas e provinciais, cenários de distintos episódios da história da ciência argentina (p.11). As autoras apresentam como recorte temporal de sua análise as décadas de 1870 e 1880, momento da expansão das fronteiras do país em direção ao sul e aos territórios do Chaco. $\mathrm{O}$ período é marcado por controvérsias científicas no campo das ciências naturais, mais especificamente na paleontologia, que se apresentava como uma nova ciência e tinha como pano de fundo de seu desenvolvimento o universo das coleções e dos museus.

De acordo com Podgorny e Lopes, podese afirmar que, na Argentina do final do século XIX, todos os significados da palavra 'museu', adquiridos e perdidos desde o século XVI, estavam ainda em uso. A palavra 'museu' poderia referir-se a um gabinete de estudo de uso exclusivo do diretor, a um grande espaço para a exibição pública ou a um símbolo da grandeza da nação e da conquista definitiva dos territórios desertos (p.11).

Os promotores dessas instituições, cujos objetivos e histórias são relatados no decorrer do livro, conheciam e tinham como referência as instituições análogas da Europa e América. A posse de um museu se equiparava a um símbolo de civilização e de estar no mundo de acordo com os valores de seu tempo. Mas esse argumento toma muitas vezes a forma de lugar-comum. Compartilhado por políticos e aficionados da ciência, o discurso no qual era apresentada a necessidade de se ter/construir um museu associava a exploração do território a um fim que parecia não se completar nunca: o conhecimento das riquezas dos povos (p.12). 
A tarefa de revelar, classificar e quantificar os recursos naturais e humanos do país, tendo como consequência a educação dos habitantes do território argentino, foi assumida como ato fundacional de quase todas essas instituições. É nessa busca incessante de organização e classificação de uma natureza até então desconhecida que podemos compreender a expressão 'o deserto em uma vitrine'. A natureza passa a ficar submetida a um ordenamento de caráter museológico e científico.

Ao estudarmos a relação do museu com a organização espacial do saber, percebemos que as disputas geradas pelo controle do mesmo se conectam com os rumos de uma instituição, uma disciplina, um indivíduo e seu trabalho. Dessa maneira, os museus de ciência ou de história natural transformam-se em um marco ideal, tanto para a compreensão do processo pelo qual o conhecimento científico fica localizado em determinados lugares quanto para a análise das relações entre os distintos atores presentes nesse espaço (p.13).

O debate acerca da ordem da natureza, da classificação e do estatuto das coleções de história natural marcou o panorama intelectual europeu das últimas décadas do século XVIII e do início do século XIX. Nesse período, a curiosidade tradicional foi substituída pela ciência, que se apresentava como um conhecimento pragmático, utilitário e especializado, em que a natureza se tornava modelo e fonte de riquezas. Os principais museus europeus desse período reuniam importantes coleções de história natural de várias partes do mundo: o inventário do mundo era complementado com o armazenamento, nosmuseus, das informações e objetos coletados em diversas expedições (p.27). Na Argentina, pesquisadores das mais variadas nacionalidades vieram em busca de espécimes para as coleções de seus museus, recolhendo, além de material botânico e zoológico, objetos etnográficos, arqueológicos e paleontológicos.

No período colonial, os 'gabinetes ibero-americanos de história natural' estavam inseridos em uma rede hierárquica em relação aos 'gabinetes metropolitanos'. Eles desempenhavam o papel de centros de recompilação de informações e objetos, para uma primeira classificação nas colônias, antes do envio parcial ou total para Madri, Ajuda ou Coimbra (p.36). Mesmo com a independência das colônias essa relação hierárquica ainda se manteve por muitos anos. É nesse cenário que podemos compreender a conduta de vários governantes, para quem o envio de amostras às instituições metropolitanas constituía uma maneira de discutir, garantir e multiplicar o efeito da exibição das peculiaridades locais (p.49).

Nessa rede de relações também en contramos 'cientistas locais', que, desejan do participar dos círculos científicos europeus, enviavam para esses grandes centros fósseis de uma fauna ainda pouco pesquisada e recebiam em troca publicações científicas. 'A troca de ossos' por papéis é apresentada pelas autoras como uma relação característica entre os museus metropolitanos e aqueles situados em países distantes dos centros europeus (p.47). A competição desenvolvida entre os museus europeus pela posse de coleções cada vez mais completas, e a possibilidade de obter a prioridade na apresentação científica dessa fauna, até então desconhecida, se refletia no aumento dos preços dos fósseis.

Os fósseis dos Pampas despertaram o olhar científico europeu desde as primei ras décadas do século XIX. O interesse por esse material e pelas instituições que o abrigavam trouxe ao território argentino um grande número de viajantes, que chegavam em busca desses ossos, 
cujo valor monetário se manteve muito alto durante praticamente todo o século XIX. Segundo Podgorny e Lopes, esse interesse marchava paralelamente ao desenvolvimento da anatomia comparada e à criação de uma nova ciência, que receberia o nome de paleontologia (p.26).

A constante busca de fósseis criou um mercado altamente lucrativo para diversos profissionais. $O$ desejo pela completude, a competição entre os países e a busca de prioridade científica acabaram por estabelecer uma dinâmica própria na venda desse tipo de material. Nesse processo, além das precauções com a transação comercial, podemostambém encontrar um mecanismo próprio da ciência do século XIX para aceitar o caráter científico do objeto a ser incorporado como verdadeiro no reino dos museus e das sociedades eruditas.

Para os cientistas, esse reino se apresentava de maneira ambivalente. Alguns destacavam a importância de se encontrarem reunidos em um mesmo espaço, como o do museu, os exemplares dos animais vistos ao longo de anos e coletados em diversas expedições: 'A natureza parecia ser maior no museu do que na própria natureza' (p.39). Para outros, o campo era o espaço onde se produzia o conhecimento científico; este surgia da observação mantida no tempo ena convivência com os fenômenos, no local onde eles eram produzidos. Devese destacar que esse segundo grupo não desqualificava o saber das bibliotecas e dos gabinetes, mas sim enfatizava a importância de levar a natureza a outro espaço, onde classificação e conhecimento deviam acontecer.

As autoras situam os museus e as coleções paleontológicas no centro da discussão do Estado argentino. Para os 'cientistas locais', o museu seria o canal para organizar a divulgação de sua própria obra e garantir sua inclusão no mundo científico internacional, situação em que o envio de material sem classificação perdia o sentido. Nesse grande projeto, no qual a nação argentina ocuparia lugar de destaque na América do Sul, surge a proposta de criação do Museu de Arqueologia e Antropologia: 'um monumento atual, onde se guardam os monumentos perdidos' (p.179). Esse museu ficaria localizado na capital da república, que deveria estar à altura das cidades dos 'países civilizados'.

Para Podgorny e Lopes, apesar do forte laço com a Europa, os modelos de museus que chegavam à Argentina estavam mediados por múltiplas leituras e experiências. O Museu Nacional do Rio de Janeiro foi por muitos anos o modelo mediador entre as instituições europeias e o ideal de museu adequado à cidade de Buenos Aires (p.250).

$\mathrm{Na}$ busca da modernização do Estado argentino, a ocupação dos territórios indígenas dos Pampas e da Patagônia desempenhou papel fundamental. A chamada 'conquista do deserto' (p.159) caracterizou-se como uma campanha de caráter militar, associada a um grupo de cientistas que tinham como objetivo 'a expansão das frontei ras científicas' (p.171). Esse território deveria ser medido por suas riquezas zoológicas, botânicas e geológicas. Além dessas três disciplinas, o projeto da expedição ainda compreendia a geografia, a astronomia, a topografia e arqueologia, diferentes saberes que, de acordo com os cientistas, complementariam o estudo da região. Essa expedição resultou na formação de uma coleção composta por diversos resquícios de materiais dos indígenas. A barbárie havia sido vencida, e seus vestígios seriam expostos nas vitrines de um museu (p.178).

As autoras nos apresentam um livro denso, rico em fontes e referências bibliográficas. Nessa pesquisa de fôlego, Podgorny e Lopes nos levam a um profundo mergulho no universo 
científico da Argentina do fim do século XIX, formado por coleções, museus e cientistas, permeado por controvérsias que evidenciam o problema da paleontologia no período analisado. As alianças estabelecidas entre os personagens estavam relacionadas com as próprias polêmicas científicas da época. Por meio da coleta, pesquisa, preservação e comunicação, os museus desempenharam papel estratégico no desenvolvimento científico do país. El desierto en una vitrina: museos e historia natural en la Argentina éleitura obrigatória para todos os pesquisadores da história da ciência e da museologia: é um livro sobre objetos, coleções, museus e ciência.

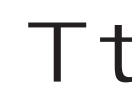

